\title{
Learning medicine by the book: reading and writing surgical manuals in early modern London
}

\author{
Elaine Leong* \\ Department of History, University College London, Gower Street, London, WC1E 6BT, \\ United Kingdom \\ *Email: e.leong@ucl.ac.uk
}

\begin{abstract}
Centred on Thomas Brugis's popular Vade mecum, or A Companion for a Chyrurgion fitted for times of Peace or War (1651), this essay considers the role of the instructional book in early modern surgical knowledge and practice. By tracing the fortuna of the Vade mecum from production to use, it shows that, far from being static texts, instructional books were dynamic objects responding and adapting to the changing needs of knowledge communities. I begin by situating the Vade mecum within surgical practice more broadly in early modern England, which shows the key role that the practices of translation and compilation played in the production of surgical manuals. Most producers of surgical manuals were practitioners-turned-authors, and their works typically drew on a mix of lived experience both at the bedside and in the library. Brugis, who was exemplary in this respect, was particularly interested in providing instructions for hands-on practices involved in surgical operations and medicine production. In the last section, which focuses on readers and users, I analyse annotations and additional writings in surviving copies of the Vade mecum to recover the agency of reader-practitioners and trace collective ownership of the book across time and space.
\end{abstract}

The shelves of early modern London booksellers were stocked with a range of vernacular medical books, priced to suit every budget. ${ }^{1}$ These books addressed all branches of medicine from physic to surgery to pharmacy and included a number of specialist treatises covering single ailments or diseases such as the pox. Often taking the form of handbooks or manuals, the majority of these texts offered instructional and practical information and were designed to aid readers from all walks of life with their everyday health practices. Manuals providing instruction on surgical procedures and related medicines were one

1 See Paul Slack, 'Mirrors of health and treasures of poor men: the uses of the vernacular medical literature of Tudor England', in Charles Webster (ed.), Health, Medicine and Mortality in the Sixteenth Century, Cambridge: Cambridge University Press, 1979, pp. 237-73; Mary Fissell, 'Popular medical writing', in Joad Raymond (ed.), The Oxford History of Popular Print Culture, vol. 1: Cheap Print in Britain and Ireland to 1660, Oxford: Oxford University Press, 2011, pp. 417-30; Fissell, 'The marketplace of print', in Mark Jenner and Patrick Wallis (eds.), The Medical Marketplace and Its Colonies c.1450-c.1850, Basingstoke and New York: Palgrave Macmillan, 2007, pp. 108-32; Elizabeth Lane Furdell, Publishing and Medicine in Early Modern England, Rochester, NY: University of Rochester Press, 2002. On instructional literature more generally see Natasha Glaisyer and Sara Pennell, Didactic Literature in England 1500-1800: Expertise Constructed, Aldershot and Burlington: Ashgate Publishing, 2003.

(C) The Author(s), 2020. Published by Cambridge University Press on behalf of British Society for the History of Science. This is an Open Access article, distributed under the terms of the Creative Commons Attribution-NonCommercial-NoDerivatives licence (http://creativecommons.org/licenses/by-nc-nd/4.0/), which permits non-commercial re-use, distribution, and reproduction in any medium, provided the original work is unaltered and is properly cited. The written permission of Cambridge University Press must be obtained for commercial re-use or in order to create a derivative work. 
of the many genres offered by booksellers. Reflecting the wide range of treatments and services performed by early modern surgeons, these manuals covered an array of topics. ${ }^{2}$ Books such as Thomas Vicary's The Surgion's Directorie, for Young Practitioners, in Anatomie, Wounds and Cures etc. (1651), James Cooke's Mellificium chirurgiae, Or the Marrow of Chirurgery (1648) and Peter Lowe's A Discourse of the Whole Art of Chyrurgery (1654) offered a general guide to the art, outlining treatments for common surgical interventions. Other titles proffered information on more specialist subjects, including military field medicine and instructions for dealing with gunshot wounds, everyday wounds and ulcers, ruptures and broken bones and bloodletting. ${ }^{3}$ Many surgical manuals offered not only introductory or refresher courses for those new to the trade but also advice on how to assess and engage with patients and use instruments in particular settings, and, of course, recipes for salves, plasters and other medicines.

The marrying of hands-on skills and book-based knowledge in surgery offers a particularly rich story for investigating notions of learning by the book. Early modern surgery was bloody and painful, and surgeons relied on lived experience and haptic knowledge to negotiate difficult procedures. Recent studies have argued that early modern surgical training was often multi-modal and included hands-on and oral instruction conducted in close master-apprentice relationships, in lectures and anatomical demonstrations organized by guilds, and in self-directed book-based learning. ${ }^{4}$ Surgical manuals thus offer opportunities for exploring the intersections between book learning and hands-on learning, generating new insights into how books might have been used to complement in-person, guild-structured training.

Among the abundance of works offered by booksellers, the Vade mecum, or A Companion for a Chyrurgion fitted for times of Peace or War (1651) was particularly well received by readers. Written by Thomas Brugis, a self-described 'doctor in Physick', the book purported to show young 'Artist[s] the use of every severall Instrument belonging to a Chyrurgion; and the vertues and qualities of all such Medicines as are needful and necessary'. ${ }^{5}$ After its initial publication, the work was repeatedly reissued, with nine editions appearing over nearly forty years, making the Vade mecum one of the best-selling surgical manuals in early modern England. ${ }^{6}$ In the 1680s, the work was translated into German by the prolific

\footnotetext{
2 On the broad range of practices undertaken by surgeons in early modern England see Margaret Pelling, 'Occupational diversity: barbersurgeons and the trades of Norwich, 1550-1640', Bulletin of the History of Medicine (1982) 56(4), pp. 484-511; Pelling, 'Appearance and reality: barber-surgeons, the body and disease', in A.L. Beier and R. Finlay (eds.), London 1500-1700: The Making of the Metropolis, London: Longman, 1986, pp. 82112; Olivia Weisser, 'Boils, pushes and wheals: reading bumps on the body in early modern England', Social History of Medicine (2009) 22(2), pp. 321-39; Seth LeJacq, 'The bounds of domestic healing: medical recipes, storytelling and surgery in early modern England', Social History of Medicine (2013) 26(3), pp. 451-68.

3 Guides geared specifically towards military and naval surgeons include John Woodall, The Surgions Mate, London, 1617; and Felix Würtz, The Surgeons Guid: or Military and Domestique Surgery, London, 1658. On gunshot wounds see Ambroise Paré, The Method of Curing Wounds made by Gun-shot, London, 1617. On wounds see, for example, Francisco Arceus, A Most Excellent and Compendious Method of Curing Woundes in the Head, and in Other Partes of the Body, London, 1588. On broken bones see, for example, Thomas Moulton, The Compleat Bone-setter, London, 1657.

4 Celeste Chamberland, 'From apprentice to master: social disciplining and surgical education in early modern London, 1570-1640', History of Education Quarterly (2013) 53, pp. 21-44.

5 Thomas Brugis, Vade Mecum, or A Companion for a Chyrurgion, London, 1651, title page.

6 Nine editions of the work were issued between 1651 and 1689. The 1651, 1653, 1657, 1665 and 1670 editions were sold by Thomas Williams, who also sold works on distillation and alchemy by John French. The sixth edition, expanded by Ellis Pratt, appeared in 1679. These editions, printed in 1679, 1681 and 1689, were sold by Thomas Sawbridge and Thomas Flesher.
} 
Hamburg-based medical practitioner and translator Johann Lange, extending its impact beyond the English-reading public. ${ }^{7}$

Like many other medical books of the period, the Vade mecum enjoyed an enduring popularity among English readers. ${ }^{8}$ A large number of copies were bought, consulted and annotated, and many continued to be used decades and sometimes even hundreds of years after their publication. ${ }^{9}$ For example, the Wellcome Library copy of the 1665 edition not only contains underlining, bracketing and recipes written in a seventeenthcentury hand, but also bears the ownership notes of two members of Jesus College, Cambridge - George Reading Leathes (1780-1836) and Charles Austin (1799-1874). ${ }^{10}$ These often multi-layered traces of use encourage us to recover the agency of readers and users.

Centred on Brugis's popular work, this essay considers the role of the instructional manual within surgical practice in early modern England. It opens by situating the Vade mecum within the context of English surgical writings more generally. Contemporary surgical manuals, I show, were often penned by practitioners-turnedauthors. As such, many drew on a mix of lived experience gained at the bedside and bookish knowledge gathered in the library. The practices of translation and compilation were key in the production of surgical manuals and were used to emphasize the author's learning in a crowded marketplace. Turning to the Vade mecum, I interrogate the processes that underlay teaching and learning surgery from the book. Brugis, I argue, was particularly keen to provide instructions for hands-on practices in surgical operations and medicine production. Finally, focusing on readers and users, I analyse annotations in surviving copies of the Vade mecum, recovering the agency of reader-practitioners and tracing collective ownership of the book across time and space. By exploring the fortuna of the Vade mecum from production to use, I contend that, far from being static texts, instructional books were dynamic objects responding and adapting to the changing needs of readers and users.

\section{Surgery and vernacular print in early modern England}

In 1692, a barber-surgeon in Newcastle upon Tyne named Henry Shaw died, leaving his shop, medical practice and a wealth of worldly goods to his wife Jane and, upon her death, to his sons. ${ }^{11}$ Surgery was undeniably a family business for the shaws. Among the usual items listed on a probate inventory were surgical instruments and twenty

7 The German edition is Vade mecum chirurgicum, oder Reise-Befehrte, vor einem Wund-Artzt zu Wasser und Lande, in Fried und Kriege nützlich zu gebrauchen ... In englischer Sprache geschrieben und zum sechstenmal gedrucket, jetzovermehret mit einem Unterricht von der Artzeney-Kunst und sieben neue Tractätlein ... / Von Ellis Prat ... in hochteutsche Sprache übersetzet durch J[ohann] L[ange] M[edicinae] C[andidatum], Hamburg, 1684.

8 There are few long-view studies of individual early modern medical titles. They include Mary Fissell, 'Making a masterpiece: the Aristotle texts in vernacular medical culture', in Charles E. Rosenberg (ed.), Right Living: An Anglo-American Tradition of Self-Help Medicine, Baltimore: Johns Hopkins University Press, 2003, pp. 59-87; and Elaine Leong, 'Transformative itineraries and communities of knowledge in early modern Europe: the case of Lazare Rivière's The Practice of Physick', in J. Andrew Mendelsohn, Annemarie Kinzelbach and Ruth Schilling (eds.), Civic Medicine: Physician, Polity and Pen in Early Modern Europe, London: Routledge, 2019, pp. 257-79.

9 The English Short Title Catalogue lists forty-nine extant copies of the work. Of these, twenty-six are of first and second editions with addendums by Brugis and twenty-three are of the revised edition expanded by Ellis Pratt.

10 Thomas Brugis, Vade mecum, or A Companion for a Chyrurgion fitted for times of Peace or War, London, 1651. This copy is Wellcome Library EPB/A/15797. See entries in A Cambridge Alumni Database, http://venn.lib.cam.ac.uk, accessed 7 May 2019. The unique identifier for Austin is ASTN819C and for Leathes it is LTS797GR.

11 Will of Henry Shaw (1692), Durham Probate Records, DPRI/1/1692/29/1. Similar bequests of books and surgical tools were also made by Nicholas Alcocke (d. 1550) and Robert Balthorpe (d. 1591): Charles Webster and 
Bookes of Chirurgery \& Physick', valued at five pounds, earmarked for his son John. ${ }^{12}$ Stored in the high chamber of the house alongside the silver and fine linens, shaw's books were clearly considered objects of substantial worth. ${ }^{13}$ The collection included works by contemporary physicians such as John Gerard, Lazare Rivière, Jean Riolan, Philip Barrough, Nicholas Culpeper and Daniel Sennert. ${ }^{14}$ Also present were a number of books on surgery and anatomy, including titles by Ambroise Paré, John Banister, William Clowes, Thomas Vicary, Peter Lowe, John Woodall, Alexander Read, Edward Edwards and Johann Vesling, and - crucially for our story - Thomas Brugis's Vade mecum. ${ }^{15}$ As the pairing together of books and instruments in the will suggests, both were considered central features of a surgeon's working life as well as valued objects in the Shaw family practice. Printed books played a key role in surgical instruction, whether in structured father-son and shop-based training practices or in self-directed learning. ${ }^{16}$

Henry Shaw's library is notable not only because it includes the who's who of early modern medical authors but also because the publication dates span a long time period, with the earliest volume, Banister's The History of Man, dating from 1578. Many titles listed had complex circulation histories and had been reissued in multiple editions over decades. Consequently, we need to take a long-view history of surgical publication in order to understand the kinds of instructional manuals surgeons like Henry shaw passed on to their sons or were circulating more generally in early modern England.

The first fifty years of English medical print consisted largely of translations from Latin and European vernaculars, including manuscripts by medieval authors and printed offerings from contemporary writers. ${ }^{17}$ As Ann Coldiron and others have suggested, working with new technology while cultivating a market for new products, early printers likely tried to minimize their financial risk by printing reliable titles with a strong circulation history either locally or in other linguistic contexts. ${ }^{18}$ William Caxton, for example,

Margaret Pelling, 'Medical practitioners', in Charles Webster (ed.), Health, Medicine and Mortality in the Sixteenth Century, Cambridge: Cambridge University Press, 1979, pp. 165-236, 176-7.

12 Shaw, op. cit. (11), DPRI/1/1692/29/3.

13 Shaw, op. cit. (11), DPRI/1/1692/29/3.

14 Shaw, op. cit. (11), DPRI/1/1692/29/4. The English books named are as follows, listed with the first and final publication year as noted in the English Short Title Catalogue: John Gerard's The Herball (1597/1636); Lazare Rivière, The Practice of Physick (1655/1678); Jean Riolan, A Sure guide or The Best and Nearest Way to Physick and Chyrurgery (1657/1671); Philip Barrough, The Method of Physick (1617/1652); and Nicholas Culpeper, The English Physician (1652/1800), A Phyiscall Directory or a Translation of the London Dispensatory (1649/1720). Shaw owned a handful of books in Dutch and Latin, which are listed in the schedule of assets as 'Ambrose Parry in Dutch, Petrus Pigrus in Dutch. Chirurgery, Eximinder, Chirurgery in Dutch and Senertus in Latin'.

15 The works are as follows, listed with the first and final publication year as noted in the English Short Title Catalogue: John Banister's The Historie of Man (1578); William Clowes's A Prooved Practise for All Young Chirurgians (1588/1637); Thomas Vicary's The Englishemans Treasure (1586/1641); Peter Lowe's The Whole Course of Chirurgerie (1597/1634); John Woodall's Surgion's Mate (1617/1655); Alexander Read's The Chirurgicall Lectures of Tumors and Ulcers (1635/1659) and A Manuall of the Anatomy of the Body of Man (1634/1658); Edward Edwards's The Whole Art of Chyrurgery (1637/1639); Johann Vesling's The Anatomy of the Body of Man (1653/1677); Thomas Brugis's Vade mecum (1651/1689).

16 Patrick Wallis has shown that alongside merchants' manuals, navigation, accountancy and medicine were also fields where print played a significant role in training and education. Patrick Wallis, 'Between apprenticeship and skill: acquiring knowledge outside the academy in early modern England', Science in Context (2019) 32, pp. 155-70, 164.

17 Early printed medical books include Here Begynneth a Litil Boke the whiche Traytied Many Gode Thinges for the Pestilence, London, 1485; and In this Tretyse that is Cleped Gouernayle of Helthe, London, 1490.

18 See, for example, Anne E.B. Coldiron, Printers without Borders: Translation and Textuality in the Renaissance, Cambridge: Cambridge University Press, 2014. 
entered medical publishing in 1490 with the Gouernayle of Helthe - a translation of Latin treatises written by the physicians John of Burgundy and Bartolomeo da Montagnana. ${ }^{19}$

In surgery, most early titles were translations of Latin, French, Italian and German texts, for example The Noble Experyence of the Vertuous Handy Warke of Surgeri (1525), a translation of Das buch der cirurgia: hantwirckung der wundarztny (1497) by the Strasbourg-based medical practitioner Hieronymus Brunschwig (c.1410-c.1512), or translations of works by late medieval figures such as Lanfranc of Milan (c.1250-1306) and Guy de Chauliac (d. 1368). ${ }^{20}$ Chauliac's works appeared as The Questyonary of Cyrurgyens with the Formulary of Lytell Guydo in Cyrurgie in 1542. Compiled from four separate tracts, The Questyonary of Cyrurgyens included a partial translation of de Chauliac's Chirurgia magna, a treatise on the treatment of leprosy attributed to the thirteenth-century Montpellier physician Bernard of Gordon, a formulary of wound and abscess remedies attributed to de Chauliac, popularly known as 'le petitie chirurgerie' or 'petit Guydon', and a partial translation of the fourth book of Galen's De Methodo medendi. ${ }^{21}$

By the mid- to late sixteenth century, the translating ventures of London book producers turned to the works of popular authors from Italy, France and the German-speaking lands, including the surgeons Giovanni da Vigo (1450-1525), Jacques Guillemeau (15501613) and Johann Jakob Wecker (1528-86). ${ }^{22}$ Translations were also marketed under the names of local English surgeons, often as part of a larger collection of tracts. The 1570s and 1580s witnessed the entry of William Clowes (1543/4-1604) and John Banister (1523/3-99?) into the London medical publishing scene. Both were active as practitioners, authors, compilers and translators whose works enjoyed continued popularity. Clowes published extensively on the pox both as an author and as a translator, bringing the Spanish physician Joannes Almenar's (fl. 1497-1502) popular treatise to English readers. ${ }^{23}$ Among other titles, John Banister offered readers a 'needefull, new and necessary treatise of chyrurgerie drawn foorth of sundrie worthy wryters, but especially of Antoinius Calmeteus Vergesatus and Iohannes Tageltius in 1575 and another book which 'gathered and translated' the works of the Basel-based physician Johann Jacob Wecker in $1585 .^{24}$

19 See entry in the English Short Title Catalogue, http://estc.bl.uk/S109870, accessed 18 November 2019.

20 On medieval surgical writings see Michael McVaugh, 'Surgical education in the Middle Ages', Dynamis (2000) 20, pp. 283-304.

21 M.C. Erler, 'The first English printing of Galen: the formation of the Company of Barber-Surgeons', Huntington Library Quarterly (1985) 48, pp. 159-71, 160-1. For an introduction to Guy de Chauliac and the Chirurgia magna see Michael R. McVaugh, 'Introduction', in Guidonis de Caulhiaco, Inventarium sive chirurgia magna, vol. 1 (ed. Michael R. McVaugh), Leiden, New York and Cologne: Brill, 1997, pp. xi-xvii. As McVaugh outlines, the Chirurgia magna, completed in 1363, was widely circulated in both late medieval and early modern Europe. The first Latin printed edition appeared in 1490, and by 1500 the work had been translated into English, French, Italian, Hebrew, Dutch and Provençal, p. xiv.

22 These appeared as The Most Excellent Workes of Chirurgerye, Made and Set forth by Maister John Vigon (1543, 1550, 1571); This Lytell Practyce of Iohannes de Vigo in Medycyne (1550?, 1552?, 1555?, 1562, 1564); Jacques Guillemeau, The Frenche Chirurgerye, or All the Manualle Operations of Chirurgerye, with divers \& Sundry Figures (1598); and Johann Jakob Wecker, A Compendious Chyrurgerie: Gathered and Translated (especially) out of Wecker (1585). A final 'newly corrected' edition of Vigo's works combined with the writings of the local surgeon Thomas Gale was published in 1586.

23 William Clowes, A Short and Profitable Treatise Touching the Cure of the Disease Called Morbus Gallicus, London, 1579; and Clowes, A Prooved Practise for All Young Chirurgians, Concerning Burnings with Gunpowder ... Heerto is adioyned a Treatise of the French or Spanish Pockes written by Iohn Almenar, London, 1588.

24 John Banister, A Needfull New and Necessary Treatise of Chyrurgerie, London, 1575, title page; and Wecker, op. cit. (22). I have not yet been able to identify 'Antoinius Calmeteus Vergesatus', but 'Iohannes Tageltius' likely refers to the Parisian surgeon and professor Jean Tagault (c.1486-1546). As Cynthia Klestinec has shown, Tagault's Institutione di cirurgia was also translated into Italian in sixteenth-century Venice. Cynthia Klestinec, 'Translating learned surgery', Journal of the History of Medicine and Allied Sciences (2017) 72, pp. 34-50. 
As Banister's works demonstrate, aside from translation, other practices of paper, pen and scissors were also central to the production of surgical texts, often warranting a mention in book titles. For instance, together with other surgeons of St Bartholomew's Hospital in Smithfield, Clowes 'reuiued, corrected and published' the anatomy of Thomas Vicary, titled as The Englishemans Treasure, or Treasor for Englishmen with the True Anatomye of Mans Body, Compiled by that Excellent Chirurgion Maister Thomas Vicary (1586), another work owned by the Shaws. ${ }^{25}$ It is notable that Vicary was described as a 'compiler' rather than an author, emphasizing the work of reading and collating in the work's production. ${ }^{26}$ Other authors who openly advertised their skills as compilers and translators on title pages include Stephen Hobbes, a translator of medical texts, who offered English readers versions of Hipporcrates' Aphorisms and the works of the Antwerp surgeon Cornelius Schylander. ${ }^{27}$ On the title page of his Margarita Chyryrgica (1610), Hobbes described the work as 'a compendious practise of chyrurgerie. Selected, and Translated, out of the Works of the most Famous physitions, and Chyrurgians of this Age ... for the benefite of all those that doe either studie, or loue the noble and worthie Arte of Chyrurgerie'. ${ }^{28}$

Working firmly within this tradition of surgical publishing, Thomas Brugis, the author at the centre of this case study, also identified compilation and translation as key practices in communicating knowledge. Brugis was somewhat unusual in offering instructional texts on both physic and surgery, working across occupational expertise and identities. While little is known about his life, paratextual materials in his publications suggest that he was a medical practitioner in Rickmansworth, Hertfordshire, and may have studied at the University of Paris under Jean Riolan the younger (1577-1657). ${ }^{29}$

Brugis's first publication, The Marrow of Physick (1639), was an all-in-one medical guide. Comprising two parts, the first consisted of a theoretical exposition, beginning with an account of the biblical creation of the world, then progressing through explanations of naturals, non-naturals and counter-naturals. The second part opened with a discussion of the various kinds of medicines followed by roughly 170 recipe-filled pages. Also included was a list of the different weights and measures, a 'Catalogue of such instruments as are requisite in private houses' and a glossary of 'hard words. ${ }^{30}$ In other words, the book offered readers both the theory and the practice of medicine in one handy volume, or, as Brugis called it, a 'pocket book', designed to be carried around or used at the bedside. ${ }^{31}$

Like many contemporary didactic texts, The Marrow of Physick drew on Brugis's extensive reading of ancient and contemporary medical sources, which he listed in a long 'Catalogue of such Authours, whose helpe I have used in this worke'. The list ran from ancient authorities such as Galen and Hippocrates, to medieval authors like Albertus Magnus and Arnald of Villanova, to contemporary writers like Jean Riolan and Jacob Wecker. He also consulted contemporary English authors such as John Banister and

\footnotetext{
25 Thomas Vicary, The Englishemans Treasure (1586), sig. *iv r.

26 The Englishemans Treasure became a key surgical text in the period. The work, or variations of it, was reprinted at least six times between its debut in 1586 and 1641.

27 Stephen Hobbes, A New Treatise of the Pestilence, London, 1603; Hippocrates, The Whole Aphorismes of Great Hippocrates (tr. Stephen Hobbes), London, 1610; Cornelius Schylander, Cornelius Shilander His Chirurgerie (tr. Stephen Hobbes), London, 1596. The latter is likely a translation of Schylander's Practica chirurgiae brevis et facilis, Antwerp, 1575.

28 Stephen Hobbes, Margaritaa Chyryrgica, London, 1610, title page.

29 Jenny Ward, 'Brugis, Thomas (b. in or before 1620, d. in or after 1651), surgeon', Oxford Dictionary of National Biography (23 September 2004), www.oxforddnb.com/view/10.1093/ref:odnb/9780198614128.001.0001/odnb9780198614128-e-3769, accessed 18 January 2019.
}

30 Thomas Brugis, The Marrow of Physick, London, 1640, pp. 85-8.

31 Brugis, op. cit. (30), p. 178. 
Philip Barrough and 'divers old Manuscripts, both Greeke, Latin and English, of sundry approved Authours, for Iudgement and Practice'. ${ }^{32}$ Twelve years later, when composing the Vade mecum, Brugis again took pains to acknowledge that his work represented the fruits of his reading and study. Assuming the role of the humble author, he unashamedly confessed, 'what I have written is meerly stolne from others, the cream of other mens wit, flowers taken out of other mens gardens ... I have laboriously collected these few flowers into one bundle, the Composition onely mine, and after that manner as never any yet was published in English'. ${ }^{33}$ In both books, Brugis openly connects his authority as a medical writer with his work as a tireless reader and gatherer of knowledge.

The emphasis that these historical actors placed on the practices of compilation and translation in the production of early modern surgical manuals is significant in a number of ways. First, it reminds us that early modern surgeons and authors saw their works within a long tradition of surgical writing going back to the efforts of ancient authorities such as Galen and further developed by medieval authors such as Guy de Chauliac and Lanfranc of Milan. As scholars have noted, generations of surgeons wrote down their art because they wanted to both communicate knowledge and skills to others and demonstrate that, aside from being a manual art, surgery was also a learned one. ${ }^{34}$ It was not uncommon for this kind of prescriptive literature to counsel young surgeons to acquire a particular level of proficiency in reading and writing Latin. For instance, in the Vade mecum, Brugis recommended that surgeons possess Latin skills so that he may not onely understand any Latine Authours, but also any Physitians Bill, and may be able to write a Bill himselfe'. ${ }^{35}$ Moreover, the emphasis on long-standing practices more commonly associated with scholastic authors and humanists, such as compilation and translation, further situates these manuals within book-based learning, aligning it with the processes through which knowledge about physic was communicated. ${ }^{36}$ other scholars have pointed to the rhetorical and literary devices used by early modern English surgeons to blur the boundaries between physic and surgery as a means of bolstering their occupational identity. I suggest that such overt demonstrations of scholarly reading and writing practices served a similar function. ${ }^{37}$ Surgeons instrumentalized vernacular print to elevate their status within the medical hierarchy, and printed surgical books played a crucial role within medical economies and politics, reflecting the hardfought battles between different factions - physicians, surgeons, apothecaries - over control of the medical 'marketplace'. ${ }^{38}$

Second, the translation, compilation and repackaging of existing works, whether medieval or contemporary, into local vernaculars involved multiple changes to the text and paratextual materials. Since translation and compilation, by definition, involved

32 Brugis, op. cit. (30), sigs. b3r-v.

33 Brugis, op. cit. (5), sigs. b8r-v.

34 Nancy G. Siraisi, 'How to write a Latin book on surgery: organizing principles and authorial devices in Guglielmo da Saliceto and Dino del Garbo', in Luis Garcia-Ballester, Roger French, Jon Arrizabalaga and Andrew Cunningham (eds.), Practical Medicine from Salerno to the Black Death, Cambridge: Cambridge University Press, 1994, pp. 88-109; Dominco Bertoloni Meli and Cynthia Klestinec, 'Renaissance surgery between learning and craft', Journal of the History of Medicine and Allied Sciences (2017) 72, pp. 1-5.

35 Brugis, op. cit. (5), sigs. a6r-v.

36 On scholarly practices see, for example, Ann Blair, Too Much to Know: Managing Scholarly Information before the Modern Age, New Haven, CT and London: Yale University Press, 2010.

37 Celeste Chamberland, 'Between the hall and the market: William Clowes and surgical self-fashioning in Elizabethan London', Sixteenth Century Journal (2010), pp. 69-89.

38 The notion of the 'medical marketplace' was first coined by Harold Cook in The Decline of the Old Medical Regime in Stuart London, Ithaca, NY: Cornell University Press, 1986. For an analytical historiographical review of this term see essays in Mark Jenner and Patrick Wallis (eds.), Medicine and the Market in England and Its Colonies, c.1450-c.1850, Basingstoke and New York: Palgrave Macmillan, 2007. 
information selection, commentary and reshaping knowledge to suit particular needs, each case was shaped in terms of the author/compiler's individual interests and local politics. ${ }^{39}$ For example, in preparing Johan Jakob Wecker's works to be published as A Compendious Chururgerie: Gathered \& Translated (especially) out of Wecker, John Banister 'founde that parte of Wecker ... [was] defective in many points ... so [he] thought good (that this worke might be the fuller) partly from other his books, partly from the most approved Authors, olde and newe, (in this point, taking so [him]selfe some larger libertie) to supplye that wanted'. Banister's annotations, which resemble modern endnotes, were designed to 'give light to the understanding of the texte, to furnish further with medicines ... and to preserve soundness of doctrine'. ${ }^{40}$ The chapter on the carbuncle, for instance, contained annotations offering explanations, additional recipes and references to the works of authorities such as Galen, Oribasius, Jean Fernel and Giovanni da Vigo. ${ }^{41}$ Thus, through processes of selecting and assembling, translators and compilers shaped considerably the knowledge within early modern surgical manuals.

In addition to highlighting their learning, writers of surgical manuals also emphasized their experiential knowledge. Given their status as practitioners-turned-authors and the fact that surgery required hands-on training, it is not surprising that many underscored their lived experience and practice in the field to establish their medical authority. In $A$ Needefull, New, and Necessarie Treatise of Chyrurgerie, for example, John Banister claimed that the work included text 'drawen foorth of sundrie worthy wryters', as well as an annex containing, as described by the author, 'certaine experimentes of mine owne inuention, truely tried, and daily of me practised' ${ }^{42}$ Decades later, Brugis adopted similar language in the Vade mecum, contending that his contribution rested not only on collecting together well-known surgical writings and translating these into English, but also on his efforts to test this know-how himself. After all, as he claimed, he had used these methods and cures for 'seven years in these late unnautrall Civil-wars', linking his experience with that of other well-known surgical authors such as Ambroise Paré and Fabricus Hildanus who openly referred to their military experiences on the battlefield. ${ }^{43}$

While this combination of authority claims extended across the different subfields of medicine, it was particularly important in areas such as surgery where technical skills played a key role. In the case of English surgery, Celeste Chamberland has shown that the Barber-Surgeons' Company adopted a multi-modal education programme to train young surgeons and help construct occupational boundaries. Unlike the education of physicians, which took place primarily in universities, surgeons learnt their craft within a master-apprentice programme, much like other trade guilds $\mathrm{did} .{ }^{44}$ Apprentices of around fourteen to twenty years of age trained for at least seven years in the household of a senior company member before being examined by senior members of the company. It also offered lifelong training to senior members, who were expected to attend weekly surgical lectures and anatomical dissections. ${ }^{45}$ In some cases, these lectures found their way into print and other more permanent media. Alexander Read's (c.1570-1641) anatomical lectures, for example, were published as The Chirurgicall Lectures of Tumors and Ulcers (1635) and A Treatise of the First Part of Chirurgerie (1638).

39 For a northern Italian example see Klestinec, op. cit. (24).

40 Wecker, op. cit. (22), sigs. ${ }^{*} 5 \mathrm{v}-* 6 \mathrm{v}$.

41 Wecker, op. cit. (22), pp. 27-33.

42 John Banister, A Needefull, New, and Necessarie Treatise of Chyrurgerie, London, 1575, title page.

43 Brugis, op. cit. (5), sig. b7v.

44 See Webster and Pelling, op. cit. (11); Margaret Pelling, 'Managing uncertainty and privatising apprenticeship: status and relationships in English medicine, 1500-1900', Social History of Medicine (2019) 32, pp. 34-56.

45 Chamberland, op. cit. (4); and Wallis, op. cit. (16). 
Many authors of surgical manuals were renowned practitioners and members of the Barber-Surgeons' Company. Both John Banister and William Clowes, whose works have been examined above, were active members of the company, serving as master (Clowes) and delivering anatomical lectures (Banister). John Woodall (1570-1643), whose Surgeon's Mate (1617) was issued in three editions and was a key source for Brugis's Vade mecum, served in a number of roles in the company, including master and anatomy master, and was responsible for training and examining apprentices. ${ }^{46}$ It is reasonable to assume that the need to create training materials for new practitioners in part drove surgeons' writing and translating activities. Clowes, for example, claimed that his A Prooved Practise for All Young Chirurgians (1588) was penned 'for the benefit of all yong Students in the Art, whose Readings and practises, [he] wish[ed] most willingly that God may prosper'. ${ }^{47}$ Relatedly, Mary Erler has argued that the publication of The Questyonary of Cyrurgyens (1542) coincided with the amalgamation of the barbers' and surgeons' companies in 1540 and was part of the company's efforts at advanced training. ${ }^{48}$ Significantly, in 1616, lectures were read aloud 'out of Guoydoes Surgery', likely a reference to The Questyonary of Cyrurgyens, indicating that the work was still part of the training schema decades after its debut in English. ${ }^{49}$ Such efforts make clear that book production was an integral part of the company's training scheme, whether for young or experienced members.

This brief survey of surgical manuals preceding the publication of the Vade mecum underscores the strong continuities in the genre across time and space. Like other medical genres, the first hundred years of surgical print in early modern London were dominated by translations and compilations of key medieval texts circulating in manuscript as well as contemporary popular printed works in Latin and in European vernaculars. Many of the titles produced in this period were written by practitioner-authors active in the Barber-Surgeons' Company who used print to bolster their occupational identity within a crowded medical market. By showcasing their scholarly credentials, they sought to establish surgery as a scholarly field of learning as well as a manual art. The flourishing field of surgical manuals, authored, compiled and translated by prominent members of the guild, suggests that these books were part and parcel of a surgeon's learning across his 'life-course', many offering advanced instruction designed to complement and extend the basic training offered in apprenticeships. ${ }^{50}$ Equally important, the centrality of textual practices such as compilation and translation meant that the content of surgical manuals continually shifted through practices of selection, omission and expansion, lending a dynamic edge to these texts.

\section{A handy guide to surgery}

As suggested by the title, Thomas Brugis's Vade mecum was designed to be a 'pocket book' containing

46 See Andrew Griffin, ‘Clowes, William (1582-1648), surgeon', Oxford Dictionary of National Biography (23 September 2004), www.oxforddnb.com/view/10.1093/ref:odnb/9780198614128.001.0001/odnb-9780198614128-e5717, accessed 3 May 2019; Griffin, 'Banister [formerly Banester], John (1532/3-99?), surgeon', Oxford Dictionary of National Biography (28 May 2015), www.oxforddnb.com/view/10.1093/ref:odnb/9780198614128.001.0001/ odnb-9780198614128-e-1280, accessed 3 May 2019; and John H. Appleby, 'Woodall, John (1570-1643), surgeon', Oxford Dictionary of National Biography (3 January 2008), www.oxforddnb.com/view/10.1093/ref:odnb/ 9780198614128.001.0001/odnb-9780198614128-e-29902, accessed 3 May 2019.

47 William Clowes, A Prooved Practise for All Young Chirurgians, [London], 1588, sig. B1v.

48 Erler, op. cit. (21), p. 159.

49 Wallis, op. cit. (16), p. 162. A second expanded and 'newly corrected' edition of Guydos Questions appeared in 1579.

50 Wallis, op. cit. (16), pp. 166, 168. 
the whole Art of Chirurgery Epitomized, that whatsoever is contained in our ancient Writers in large Volumes, is here in effect contracted in a little room, with all the lines, shadows, and dimensions, as well as if it were in a large piece. ${ }^{51}$

That is, despite its portable size, the Vade mecum contained the entirety of the surgical art. Unlike his earlier Marrow of Physick, Brugis did not include a theoretical section. Instead, after a lengthy preface, he opened the work with a list of instruments a surgeon ought to have in his 'handsome Plaister Box and Salvatory', including incision knives, probes, quills, forceps, razors, headsaws, trasine, catheters, cupping glasses, cauterizing irons, sponges and a range of plaisters, unguents, oils and salves. ${ }^{52}$ He then described the most important instruments and medicines one by one, offering concise explanations on selection criteria and use, and on the maintenance of the instruments. ${ }^{53}$ This was followed by a collection of detailed recipes for making various medicines and the virtues of simples; further step-by-step instructions on how to use specialist tools such as the trasine, headsaw and various syringes; and an overview of how to treat wounds, ulcers and fractures. ${ }^{54}$ Brugis then offered a list of simples and their operations as astringents, corrosives and so on, and a list of quid pro quos; that is, suggested substitutions for unavailable simples or materia medica. ${ }^{55}$ The work ended with instructions for making 'Reports before a Judge of Assize, of any one that hath come to an untimely end', and a list of critical days. ${ }^{56}$ The wide range of information presented in the book is exemplified by the frontispiece, which shows a portrait of the author (we assume) in the centre surrounded by four vignettes depicting surgery and medicine production (top left and right) and distillation equipment and surgical instruments (bottom left and right) (Figure 1). A visual epitome of the book's contents, it not only reinforced the book's purpose, but also showcased the breadth of activities that early modern surgeons performed.

The Vade mecum's focus on instrument use and medicine production departed from the usual form and content of surgical manuals across Europe since the Middle Ages. As Michael McVaugh and Nancy Siraisi have shown, surgery became 'text-based' in northern Italy in the twelfth and thirteenth centuries when a new tradition of surgical writing emerged that was distinct from writing in other areas of medicine. ${ }^{57}$ McVaugh contends that Guglielmo da Saliceto likely started this practice of writing for surgical 'colleagues' and his efforts marked 'transformation of surgical training from private - oral and personal - instruction to public, almost collective teaching. ${ }^{58}$ Authors like Guglielmo were attracted by the 'authoritative knowledge of authors such as Galen, Avicenna and Albucasis' in the craft and the 'possibility of structuring and ordering that knowledge into the kind of teachable doctrina characteristic of other kinds of more prestigious

51 Thomas Brugis, Vade mecum, or, a companion for a chirvrgion, London, 1657, sig. A3v.

52 Brugis, op. cit. (5), pp. 1-6.

53 Brugis, op. cit. (5), pp. 7-11

54 Brugis, op. cit. (5), pp. 11-120, 121-36, 137-62, 162-78.

55 Brugis, op. cit. (5), pp. 178-85, 186-90.

56 Brugis, op. cit. (5), title page. In the1650s, it was still relatively uncommon for medical practitioners to act as expert witnesses. As the literature suggests, this practice gradually became more commonplace in the late seventeenth and early eighteenth centuries. In this context, Brugis makes a bold step by including this information. The sixteen-page chapter is presented at the end of the Vade mecum and presents rules taken out of Ambroise Paré's works with emendations by Brugis himself: Brugis, op. cit. (5), pp. 191-206, 207-8 (critical days). See, for example, Katherine D. Watson, Forensic Medicine in Western Society: A History, London and New York: Routledge, 2010; and Vanessa McMahon, "Reading the body: dissection and the "murder" of Sarah Stout, Hertfordshire, 1699', Social History of Medicine (2006) 19(1), pp. 19-35.

57 McVaugh, op. cit. (20); Siraisi, op. cit. (34).

58 McVaugh, op. cit. (20), p. 288. 


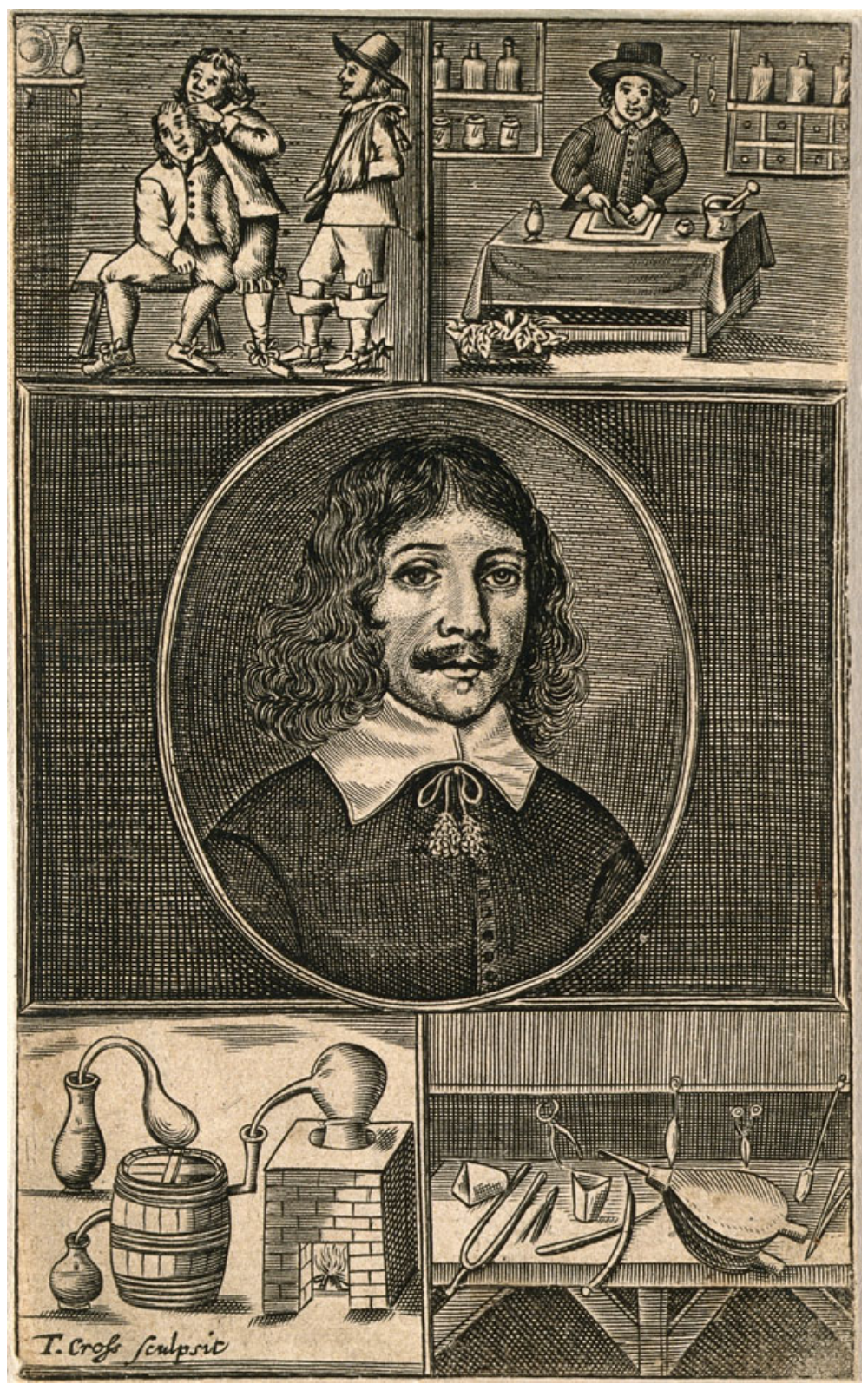

Figure I. Thomas Brugis, Vade mecum (London, 165I), frontispiece. Engraving by Thomas Cross. See https://wellcomecollection.org/works/kmp8rb8t.

schools - of arts, medicine and law'.59 Consequently, although there was some diversity among early learned surgical manuals, they all covered a common set of materials in a finite number of arrangements. Many of these late medieval and early Renaissance texts, such as those by Chauliac or Lanfranc, began with a chapter devoted to anatomy 
and detailed the causes and signs of conditions such as wounds, ulcers, dislocations and fractures, and their treatments, including medicinal remedies. ${ }^{60}$

As part of a larger effort to revive medieval surgical texts and practices of compilation and translation, most early modern English surgical publications also followed this general form. ${ }^{61}$ For example, the popular Mellificium chirurgiae (1648) by James Cooke offered readers 'the Art of Chyrurgery in its foure parts, with all the severall diseases unto them belonging. Their Definitions, Causes, Signs, Prognosticks and Cures, both generall and particular'. It included instructions for dealing with tumours, ulcers, fractures and wounds as well as advice on how to separate 'parts unnaturally joyned', such as in cases of tongue-tie or when removing 'things superfluous' like moles, wens or kidney stones. ${ }^{62}$

In the Vade mecum, however, Brugis decided to go another way. After all, 'the definition of wounds' had been 'so much treated of already in all Authours' and rather than repeat information that was readily available, he wanted to 'shew the Artist what he ought to do, when he is called to a wounded Patient'. For Brugis, this kind of practical instruction 'shall suffice for this Discourse ... for if [he] should set down all particulars, [he] should increase [his] book far beyond the bounds of a pocket book, for which [he] intended it, that it might be ready upon all occasions to re-in-force a weak memory'. If a reader required additional information, he could, 'as he meets with Authours to his purpose, to collect notes of what he finds wanting here'. ${ }^{63}$ In other words, Brugis imagined the Vade mecum as serving a function similar to that of a modern reference book, offering concise, practical instructions for surgeons who might need to brush up on particular operations. While Brugis addressed the text to 'yong artist[s]', experienced surgeons would also have found the information it contained helpful in unfamiliar situations. Its portable size meant that it could easily be brought along to consultations, and its simple organization made for quick and easy informational retrieval. Brugis's encouragement to readers to 'collect notes' suggests that his ideal reader was one who might complement the Vade mecum by reading other texts to further their surgical education.

The contents of the Vade mecum reflect the kinds of knowledge Brugis considered pertinent to everyday surgical practice and essential for those new to the trade, including instructions for the use and care of instruments; directions for tricky procedures; treatment advice for wounds, ulcers, fractures and dislocations; and detailed recipes for medicine production. Throughout the volume, he prioritized advice and know-how gained from personal, lived experience. ${ }^{64}$ For example, in the section on the use and care of instruments, the entry on incision knives informed readers that the instrument is used to "cut the skin or flesh upon needfull occasions, in paring away the putrid part of a gangrenous member'. The instrument should always be kept 'cleane and bright, by being rubbed dry after it hath been used and sharp as any rasour'. Crucially, surgeons should

60 Nancy G. Siraisi, Medieval and Early Renaissance Medicine: An Introduction to Knowledge and Practice, Chicago: The University of Chicago Press, 2009; Klestinec, op. cit. (24).

61 There are, as always, exceptions to the rule. For example, John Banister's An Antidotarie Chyrurgicall (1589) was organized by type of medicament and listed alphabetically from balmes to cataplasme to unguents, and Edward Edwards's The Analysis of Chyrurgery, Being the Theorique and Practique Part Thereof (1636) presented over a hundred pages of information in diagrammatic form resembling the charts made popular by philosophers such as Petrus Ramus.

62 James Cooke, Mellificium Chirurgiae, Or the Marrow of Chirurgery, London, 1648, title page and table of contents.

63 Brugis, op. cit. (5), pp. 162, 177-8.

64 For a recent overview of the importance of experience in medieval and early modern medicine see Elaine Leong and Alisha Rankin, 'Testing drugs and trying cures: experiment and medicine in medieval and early modern Europe', Bulletin of the History of Medicine (2017) 91, pp. 157-82. On medical practitioners collecting know-how see Michael Stolberg, 'Learning from the common folks: academic physicians and medical lay culture in the sixteenth century', Social History of Medicine (2014) 27, pp. 649-67. 
'hide it from Patients sight with a cloath, and also all other sharp instruments, for divers reasons' ${ }^{65}$ In prompting readers to be mindful of patients' anxieties and fears of sharp knives and such, Brugis's advice went beyond the maintenance of surgical tools to the management of medical encounters.

Brugis's instructions demonstrate a keen awareness of the different materials used to make surgical tools, their specific applications and their requirements for maintenance. For instance, using detailed and carefully worded instructions, he advised surgeons to keep on hand 'very clean' syringes made of tin or silver and ensure that one is used for 'watry injections, another for oyly'. ${ }^{66}$ He paid similar attention to materials in his instructions for using the stitching needle, another must-have tool for surgeons, directing practitioners to keep at least three different-sized, well-oiled and rust-free needles in their box, all of which should be 'well set, and ready armed with green, or red silk oyled'. If the practitioner found himself out of silk, he could use thread, but then he would need to rub it with 'some kinde of emplaister'. ${ }^{67}$

Apart from advice on the care and maintenance of instruments, Brugis also offered his readers detailed descriptions of how to employ them, which often entailed relating how surgeons could use their senses to gauge the different stages of use. Guidance of this kind was especially pronounced in the instructions for using the trephine, an alternative to the trepan advocated by John Woodall in his Surgeon's Mate. ${ }^{68}$ Modelled on Woodall's text, Brugis's instructions for using the trephine were particularly comprehensive, presumably because the procedure was likely rarely performed and step-by-step instructions would aid new practitioners as well as serve as an aidememoire to experienced surgeons. Designed to perforate the skull, the instrument consisted of a long shaft with a toothed wheel armed with a steel pin in the centre. The surgeon was instructed to place the instrument on the head, using the steel pin as a guide to position the trephine and secure its teeth onto it. This first step served to mark the point at which the tool would perforate the skull. Once completed, the surgeon should take the instrument off, clean the teeth of the wheel and remove the pin, returning the screw to the head and 'by the agitation of his hand onely to and fro to pierce' until the teeth of the wheel go halfway through. At this point, Brugis advised the practitioner to pull the instrument out and clean it again before reapplying it to the head and 'pierc[e] by the motion of his hand to and fro, untill he have in all parts gone through the cranium.' Throughout the process, the practitioner should 'diligently regard in the tender observant motion of his own hands' the precise moment this phase of the procedure was completed; that is, when 'he that pierceth shall sensibly feel when the bone is penetrated through on each part'. ${ }^{69}$ At this point, the instrument could be withdrawn with the piece of cranium attached.

It is telling that while Brugis's instructions are detailed and clear, there are still silences. For instance, there is no mention of the practitioner needing to shave the patient's head before the procedure or pointers on whether to remove the skin flap before attaching the instrument or with the bone when withdrawing it. How should the practitioner position the patient and what kind of pain-management strategies should be employed? These silences remind us of the vast amount of assumed knowledge required

65 Brugis, op. cit. (5), p. 7.

66 Brugis, op. cit. (5), p. 145.

67 Brugis, op. cit. (5), p. 9.

68 John Woodall, The Surgeons Mate or Military \& Domestique Surgery, London, 1639; John H. Appleby, 'New light on John Woodall, surgeon and adventurer', Medical History (1981) 25, pp. 251-68.

69 Brugis, op. cit. (5), pp. 139-40. 
in these kinds of procedures and that in surgery, as with other knowledge fields, textual knowledge rarely conveyed all the required know-how for action. ${ }^{70}$

Trepanning was a risky procedure and was acknowledged as such at the time. Brugis warned readers that 'there is a great care to be taken by the Artist in the manner of the piercing', taking pains to specify the various ways of removing a piece of bone. Of all the dangers involved in drilling into a skull, the most serious one was to go too deeply into the brain matter when trying to press the instrument through the bone. This was the reason Brugis recommended using the trephine over the traditional trepan: its 'ragged raper head' offered more points of contact than the trepan, which relied on a single small screw to fasten the instrument to the head, thereby increasing the chances of inadvertently going too deep, too fast. Even with the trephine, however, surgeons could still forget to remove the guiding pin in the centre of the instrument before returning it to the head. Because the pin was longer than the teeth of the wheel, it would also pierce into the brain matter. Multiple removals of the toothed wheel for 'cleaning' enabled the surgeon to gauge how far he had penetrated through the cranium. Ending this section with warnings of the danger and precariousness of this particular operation, Brugis 'adviseth the young Artist to make trial on a Calves-head, or the like subject, before he put it in practice upon a man; for indeed a Surgeon can never be too fearful of omission, or of over-doing, ${ }^{71}$

Brugis's precise and practical instructions extended beyond the use of surgical instruments to processes of medicine production. In the entry on making 'Sir Philip Paris Emplaister', for example, readers were not just given a list of ingredients and a bare-bones description of production methods, as was customary. ${ }^{72}$ Instead, Brugis spelled out exactly what kind of vessel to use ('earthen pan, well glased'), what heat source to employ ('gentle fire of coales'), what changes to look for in the material ('encrease fire till the red turne grayish') and how to determine at what moment a recipe was complete ('drop a little upon a trencher, if it cleave not thereto, then it is enough'). Paying similar attention to detail, Brugis also urged surgeons to ensure that all the gums used in the recipe were 'finely powdered, dissolved in sacke or Vineger, and strained through a canvas, and the vinegar or sacke evaporated at the fire', and warned them not to over- or under-boil, which would result either in hard plasters with evaporated ingredients or plasters that would not stick. Reading the vivid instructions, readers might feel as if an experienced practitioner were standing next to them as they performed these tricky procedures, guiding them along the way with warnings about potential pitfalls.

Like many other multi-editioned instructional works, the Vade mecum was by no means a static text. Early modern book producers were sensitive to changes in current medical ideas and attuned to market needs, and reworked titles accordingly. In so doing, they also continually shaped and reshaped the parameters of instructional medical literature. In preparing the second edition of the Vade mecum in 1657, in addition to adding an appendix on the 'rules for vomiting and purging', Brugis openly aired his frustration about his local medical landscape, warning readers against visiting 'Empericks, silly impudent women and fools', particularly an 'illiterate, bold, impudent' woman living nearby in 'Ruslippe' who was clearly in competition with him for patients. ${ }^{73}$ In this manner, he deftly

70 See, for example, H. Otto Sibum, 'Reworking the mechanical value of heat: instruments of precision and gestures of accuracy in early Victorian England', Studies in History and Philosophy of Science Part A (1995) 26, pp. 73-106; Pamela H. Smith, 'Why write a book? From lived experience to the written word in early modern Europe', Bulletin of the German Historical Institute (2010) 47, pp. 25-50.

71 Brugis, op. cit. (5), pp. 140-2.

72 Brugis, op. cit. (5), pp. 35-6. For an overview of recipes in early modern England see Elaine Leong, Recipes and Everyday Knowledge: Medicine, Science and the Household in Early Modern England, Chicago: The University of Chicago Press, 2018.

73 Brugis, op. cit. (51), pp. 223-30, esp. pp. 223-4. 
positioned his text within squabbles in local medical markets and attempted to reinforce traditional hierarchies of medical authority.

Decades later, the title underwent another transformation in the hands of the physician Ellis Pratt, who produced a new, expanded edition featuring his notes on surgical practices. Although he retained the same title, Pratt made a number of changes, including adding the theoretical part of surgery and physic, rendering it less of a 'vade mecum'. The title page of the 1679 edition boldly claimed that it now contained 'an Institution of PHYSIC with seven New Treatises. Viz. of Tumours, Wounds, Ulcers, Fractures, Dislocations, Lues Venerea, Anatomy'. ${ }^{74}$ In one fell swoop, Pratt negated the distinctiveness of Brugis's practice-oriented text, rendering it similar to others on the market. It was this edition that the Hamburg-based medical practitioner and translator Johann Lange wrought into German in the 1680s.

\section{Reading and using the Vade mecum}

From its conception, the Vade mecum was designed to appeal to both surgeons and general readers. In addition to the pedagogical functions described above, the book also served as a self-help guide for patients, aiding them in basic healthcare and shaping their medical encounters. In the section of the preface explicitly addressed to patients, Brugis warned them to stay away from 'Mountebanks, Empericks, Quacksalvers, Paracelsians (as they call themselves) Wizards, Alcumists, Poor-vicars, cast Apothecaries, and Physitians men, Barbers, and Good-wives that professe great skills, go with the name of Doctor'. Instead, if they needed to see a surgeon, they should turn to Brugis's handy guide to identify good practitioners and for advice on how to engage with them to ensure they receive aid. $^{75}$

In gearing the Vade mecum towards users of medical services, Brugis was participating in a broader contemporary movement. English medical authors often used print as a medium to forward their political agendas, and instructional manuals occupied a central place within many of these debates. As scholars have demonstrated, authors of didactic literature across different knowledge fields employed the rhetoric of utility or the "common good' as a way of justifying their works and as a marketing strategy. This strategy was particularly common in the 1650s in the aftermath of the English Civil War when authors in a number of fields instrumentalized print to advocate open access to knowledge. Alongside theology and law, medicine was targeted as an area where crucial knowledge was often transmitted in Latin and kept from the 'common man'. The use of vernacular print enabled the everyman to take charge of his own health ${ }^{76}$ In this manner, instructional texts, such as the Vade mecum, formed both the basis of primary care within the household and the very foundation of patient-practitioner relationships, influencing the power dynamics between the two parties. Informed patients were able to interpret the bumps and boils on their own bodies, empowering them to design and direct their own programmes of surgical care, commission practitioners for different tasks and, crucially, avoid 'the cut' when possible. ${ }^{77}$

74 Thomas Brugis and Ellis Pratt, Vade mecum ... The Sixth Edition, Amended and Augmented, London, 1679, title page.

75 Brugis, op. cit. (5), sigs. b4r-v.

76 Charles Webster, The Great Instauration: Science, Medicine and Reform, 1626-1660, London: Duckworth, 1975, particularly Chapter 4 on the prolongation of life. See also discussions in Lauren Kassell, 'Secrets revealed: alchemical books in early modern England', History of Science (2011) 49, pp. 61-125; J. Andrew Mendelsohn, 'Alchemy and politics in England 1649-1665', Past \& Present (1992) 135, pp, 30-78.

77 On patient-directed surgical care see Weisser, op. cit. (2); and LeJacq, op. cit. (2). 
Whether as practitioners or as patients, readers eagerly took to Brugis's Vade mecum, as evidenced by the heavily annotated copies of the book that survive in archives and libraries. ${ }^{78}$ The previously mentioned Austin-Leathes volume in the Wellcome Library, for example, contains assorted marginal notes written in by owners over hundreds of years after publication. Judging by the handwriting, a seventeenth-century owner added a recipe for elderberry or blackberry wine on the front flyleaf. The same reader added a number of manicules and other signs to mark out passages throughout the book and noted his/her experiences with particular cures. For example, under a nosebleed remedy that involved blowing the ashes of egg shells or paper into the nose, he/she noted that powder of 'bole armanake' 'hath been experiemented' ${ }^{79}$ Another reader, possibly the nineteenth-century reader who signed 'GDH 37', covered a blank front opening with scrawls, including medical terms such as sinew and issue, nursery rhymes such as 'Rub a dub dub' and drawings of Chinese crackers. ${ }^{80}$ Additionally, aside from signing his name, Leathes also sketched a small box labelled 'Mr Symes Pocket case of operating knives' on the front pastedown, thereby connecting the work with contemporary surgical culture.

Marks in copies of the Vade mecum also suggest that users read the book in conjunction with a range of other works. For example, the early modern reader of the Austin-Leathes volume noted under the section on oil of vitriol that 'In Mr Ramseys Treatise of poysons he speaks of the danger of Taking oyl of vitrioll inwardly'. He/she was referring to William Ramesey's De Venenis, or A Discourse of Poysons Their Names, Natures and Uses (1663), in which Ramesey included vitriol as a poison, citing examples from Johannes Crato von Krafftheim's collection of medical cases and letters. ${ }^{81}$ In some instances, readers required more space than the margins for their notes and annotations. A copy of the 1652 edition of Vade mecum now in the Huntington Library was bound with additional paper filled with information about herbs and recipes, much of which was gleaned from other printed or manuscript works. ${ }^{82}$ One recipe added by a reader was for making the popular 'Lucatellies Balsum'. Brugis named this unguent as one of eight medicaments crucial for any surgeon's 'salvatory', but did not provide any production information. ${ }^{83}$ Lucatella's balsam was a popular medicine in the period, and different recipes to make the drug circulated widely in contemporary printed and manuscript recipe books. The ubiquity of the recipe may account for Brugis's omission of it, having likely assumed that readers would either use their preferred formula to produce the salve or purchase it ready-made. ${ }^{84}$ Aside from

78 On marginalia see William H. Sherman, Used Books: Marking Readers in Renaissance England, Philadelphia: University of Pennsylvania Press, 2008. On medical reading practices in early modern England see Mary E. Fissell, 'Readers, texts, and contexts: vernacular medical works in early modern England', in Roy Porter (ed.), The Popularization of Medicine, 1650-1850, London: Routledge, 1992, pp. 72-91; Peter Murry Jones, 'Reading medicine in Tudor Cambridge', Clio Medica: Perspectives in Medical Humanities (1995) 30, pp. 153-83; Elaine Leong, “'Herbals she peruseth": reading medicine in early modern England', Renaissance Studies (2014) 28, pp. 556-758. On annotations in learned medical books see Daniel Margocsy, Mark Somos and Stephen N. Joffe, The Fabrica of Andreas Vesalius: A Worldwide Descriptive Census, Ownership and Annotations of the 1543 and 1555 Editions, Leiden and Boston: Brill, 2018.

79 Wellcome 15797/A, op. cit. (10), p. 232.

80 Wellcome 15797/A, op. cit. (10), front flyleaves.

81 Ramesey refers to Joannaes Crato, Consiliorum \& epistolarum medicinalium ... liber quintus, Frankfurt, 1594.

82 Huntington Library, Rare Book 124144 and HN MS 59539, for the gathering of manuscript notes.

83 Huntington Library, Rare Book 124144, op. cit. (83), front flyleaf r-v, p. 2.

84 Recipes in contemporary household manuscript books include Wellcome Western MS 1026, p. 6; Wellcome Western MS 3768, fol. 10r; Wellcome Western MS 4047, fol. 56v; and Wellcome Western MS 4338, fol. 203r. The recipe also appears in Cooke, op. cit. (62), p. 467-9; and in Natura Exenterata: or Nature Unbowelled By the most Exquisite Anatomizers of Her, London, 1655, p. 177. Additionally, the medicine was available for purchase, as evidenced by its inclusion in the 'Catalogue for some choice Medicines which I have by me ready prepar'd' in 
writing out the entire recipe, the reader also used his/her notes to refer to information contained in other printed works. For example, one entry reads, 'sow thistle for a 100 things see 500 . 208. In Culpeper', and another 'piamounts secrets see 186 for ye eyes and for ye iandise .285 .307 see for st johns oyle 184 pills of turpentine for ye stomake'. ${ }^{85}$ These entries referred to two well-known publications - Nicholas Culpeper's The English Physician (1652) and Girolamo Ruscelli's The Secretes of the Reuerende Maister Alexis of Piemount (1558). In both cases, the page numbers provided suggest that the notes were part of a note-taking system designed to allow easy return to entries on particular materia medica or ailments in different books within a library, a practice which hints at wider activities of medical reading.

The myriad surgical titles featured in this article, along with Brugis's Vade mecum, were part of a broader medical book culture which crossed the constructed boundaries between physic, surgery and pharmacy. For instance, the breadth of Henry Shaw's library not only brings to the fore a family with wide-ranging medical knowledge but also reminds us of the multifaceted medical role taken on by barber-surgeons during this period. ${ }^{86}$ As Brugis articulated in the preface,

Physick, Pharmacy, or Chyrurgery ... they are all three so depending one upon another, that they cannot be separated, and in times past they were all performed by one man, though now pride and idlenesse hath made them three professions; yet to say truly, whosoever professeth one, must be skilfull in the other two, else he cannot perform his work aright. ${ }^{87}$

Published in the 1650s and read until the late 1800s, copies of Thomas Brugis's Vade mecum document dynamic conversations over time and space. Earlier sections outlined how book producers saw the Vade mecum as a malleable text, open to additions and other changes. Readers also viewed the text in much the same way. To many, it was a compendium of useful knowledge, ready to be personalized and updated with their other medical readings and experiences. Practical knowledge about surgery was continuously kept in use by processes of textual and epistemic adjustment. In order for knowledge, particularly instructional knowledge, to remain relevant and useful, it had to be updated. The text and individual copies of the material book, then, became active sites of negotiation between existing knowledge and subsequent revisions.

\section{Conclusion}

Centred on Thomas Brugis's Vade mecum, this essay has explored the notion of learning surgery from a book. From the early sixteenth century onwards, the shelves of London booksellers were stocked with a wide range of surgical books. Like other genres of vernacular print in this period, surgical print was characterized by translations of Latin and European vernacular texts penned by both medieval and contemporary authors. Authors of English surgical manuals emphasized their learning and use of scholarly reading and writing as key in the production and transfer of surgical knowledge, complicating long-held assumptions about vernacular and learned medicine. In the sixteenth century, these practices were employed by prominent members of the Barber-Surgeons' Company,

George Hartman's The Family Physitian, or A Collection of Choice, Approv'd and Experience'd Remedies, London, 1696, p. 526. At the end of the seventeenth century, Londoners could purchase this medicine at sixpence for one ounce at Hartman's house at the 'lower end of Cherry-Garden Street, near Jamaica House in Rotherheith' (p. 528). 85 HN MS 59539, op. cit. (83), unpaginated.

86 Shaw, op. cit. (11).

87 Brugis, op. cit. (5), sigs. b6v-b7r. 
and surgical publishing was instrumentalized by historical actors in response to local occupational politics, and as a way to construct authority claims. The involvement of company masters and wardens also suggests a connection between advanced training provided by the guild, such as anatomical lectures, and the printed books made available.

Within the rich field of surgical books, Brugis's Vade mecum had a distinct practical bent and was designed to impart quotidian skills and knowledge needed to run a surgical practice. In many ways, the story of the Vade mecum is one of medical knowledge in use. Readers were informed about the required tools (made in the right materials) to keep on hand, along with instructions for using and maintaining them. The unusually detailed recipes for medicine production and lengthy descriptions of how to use instruments such as the trephine made the Vade mecum a useful instructional guide. In its ability to render such information readily accessible, the printed book served as both an aidememoire to experienced practitioners and an introduction to the field for those new to the craft. It is no wonder the Vade mecum was one of the most popular surgical manuals in seventeenth-century England.

In a field such as surgery, we often assume that haptic knowledge was transferred primarily via in-person training. But Brugis's description of how to use the trephine reminds us that this kind of knowledge was also codified in writing. In this sense, this story of surgical print joins recent investigations into how-to knowledge and the connections between 'making and knowing'. Thus far, these studies have largely concentrated on artisanal and craft activities, pointing out silences in textual knowledge and showing us how makers adjusted to changing materials and environments. ${ }^{88}$ Further studies of practical surgical writing could extend these conversations not only by showing how surgeons paid heed to the properties of materials or environments but also by demonstrating how they adapted their work to particular human bodies and individual patients. Undoubtedly, additional analyses of the fortuna of different authors and of various types of surgical books - practical, short hands-on guides such as Brugis's or lengthier learned treatises - will illuminate our views of how practical knowledge and skills were transmitted in the early modern period.

Acknowledgements. My warmest thanks to participants of the Learning by the Book Conference at Princeton and working group at the MPIWG, audiences at the Early Science Seminar at the University of Cambridge and the two anonymous reviewers for their helpful suggestions and feedback. I am privileged to work with Mary Fissell on the Reading Early Medicine Project and this article has hugely benefited from our conversations and collaboration. Finally, my gratitude goes to my co-editors, Angela Creager and Mathias Grote, who have been exemplary collaborators over the past few years. Research for this essay was conducted as part of my Wellcome Trust-funded project Technologies of Health c.1450-1750 (grant number 209835/Z/17/Z).

88 There is a rich and vibrant literature on this. Recent studies include Sven Dupré, 'Doing it wrong: the translation of artisanal knowledge and the codification of error', in Matteo Valleriani (ed.), The Structures of Practical Knowledge, Cham: Springer, 2017, pp. 167-88; Thijs Hagendijk, 'Learning a craft from books: historical re-enactment of functional reading in gold- and silversmithing', Nuncius (2018) 33, pp. 198-235; Pamela H. Smith, 'In the workshop of history: making, writing, and meaning', West 86th: A Journal of Decorative Arts, Design History, and Material Culture (2012) 19, pp. 4-31.

Cite this article: Leong E (2020). Learning medicine by the book: reading and writing surgical manuals in early modern London. BJHS Themes 5, 93-110. https://doi.org/10.1017/bjt.2020.7 